\title{
Instability of shallow lakes: A matter of the complexity of factors involved in sediment and water interaction?
}

\author{
I. de Vicente ${ }^{1,2, *}$, V. Amores ${ }^{1}$ and L. Cruz-Pizarro ${ }^{1}$ \\ ${ }^{1}$ Instituto del Agua, Universidad de Granada, 18071 Granada, Spain \\ 2 Institute of Biology, University of Southern Denmark, 5230 Odense, Denmark \\ *corresponding author: ivicente@ugr.es
}

\begin{abstract}
Instability and extreme fluctuations in water quality characterizing shallow lakes are to a large extent due to rapid changes in the internal supply rates of nutrients. In fact, is in these systems that sediment and water interaction plays a major role in nutrients' dynamics. For this study, a double-approach perspective with both field measurements and laboratory experiments has been used in order to determine the contribution of physical, biological, and chemical mechanisms to nutrients' dynamics in two shallow adjacent lakes in Andalusia (Spain). Despite their geographic proximity, strong differences between the study systems have been recognised. In the Lake Honda, the high nutrient concentrations, which ultimately support a large algal biomass, are the result of: $i$. Resuspension of the surface sediment favoured by its morphometry, hydrologic regime and sediment granulometry. ii. Intense organic matter mineralization due to the labile nature of the organic settled matter (planktonic). In Lake Nueva, by contrast, physical constrains (i.e. wind-induced resuspension) have a limited effect due to the coarse surface sediment and to the development of macrophytes (Najas marina, Potamogeton pectinatus). In addition, the structurally more complex organic matter of its sediment regulates the low nutrients turnover. In this lake, nutrient exchange rates across the sediment-water interface are also controlled by chemical processes, such as $\mathrm{P}$ adsorption onto $\mathrm{CaCO}_{3}$, a mechanism that is favoured by the high $\mathrm{Ca}^{+2}$ concentration in the interstitial water. In this way, the joint effect of physical, chemical, and biological mechanisms determine the fast nutrients' benthic regeneration in Lake Honda, while in contrast, a large fraction of the nutrients present in the sediment of the Lake Nueva is in particle form.
\end{abstract}

Keywords: instability, shallow lagoons, benthic nutrient regeneration

\section{RESUMEN}

La inestabilidad y las extremas fluctuaciones en la calidad del agua que caracterizan a los lagos someros, se deben en gran medida, a cambios rápidos en la carga interna de nutrientes. De hecho, es en éstos sistemas, donde la interacción agua-sedimento juega un papel esencial en la dinámica de los nutrientes. Para este estudio, se ha empleado una doble aproximación, basada tanto en datos de campo como en experimentos en laboratorio, para determinar la contribución de mecanismos físicos, químicos y biológicos a la dinámica de los nutrientes en dos lagunas costeras en Andalucía (España). A pesar de su proximidad geográfica, se han reconocido fuertes diferencias entre ambos sistemas. En la laguna Honda, las elevadas concentraciones de nutrientes, que en última instancia soportan una elevada biomasa algal, son el resultado de: i. Resuspensión del sedimento superficial, favorecida por la morfometría, el régimen hídrico y la granulometría de su sedimento. ii. Intensa mineralización de la materia orgánica debida al carácter lábil de la materia orgánica sedimentada (origen planctónico). En la laguna Nueva, por el contrario, el impacto de los factores físicos (p.e. resuspensión inducida por el viento) se encuentra limitado por la gruesa granulometría del sedimento superficial asi como por el desarrollo de macrófitos (Najas marina, Potamogeton pectinatus). Más aún, la naturaleza estructuralmente más compleja de la materia orgánica presente en su sedimento determina unas menores tasas de regeneración de nutrientes. En esta laguna, las tasas de intercambio de nutrientes a través de la interfase agua-sedimento se encuentran, además, controladas por procesos químicos, tales como la precipitación de $\mathrm{P}$ sobre $\mathrm{CaCO}_{3}$, mecanismo que se encuentra favorecido por las elevadas concentraciones de Ca ${ }^{+2}$ presentes en el agua intersticial. Por tanto, es la conjunción de mecanismos físicos, químicos y biológicos los que determinan la rápida regeneración béntica de nutrientes en la laguna Honda; mientras que, por el contrario, una importante fracción de los nutrientes presentes en el sedimento de la laguna Nueva se encuentra en forma particulada.

Palabras clave: inestabilidad, lagunas someras, regeneración béntica de nutrientes 


\section{INTRODUCTION}

Lake sediments play an outstanding role in limnological studies as they can both reflect and affect what is occurring in the overlying water column (Håkanson, 1984). In fact, sediments are the product of lake life and, consequently, they reflect the lake type. This notion was firstly stated by Lundqvist, who made several major investigations on the relationships between lake type, sediment type and lake surroundings during the thirties and forties (Lundqvist, 1938; 1942 in Håkanson, 1984).

In this sense, sediments can be regarded as a bank of information about environmental changes occurring in both the water body and in the catchment area (Kalff, 2002; Luque and Juliá, 2002; Schmidt et al., 2002). Accordingly, there are many studies focused on the reconstruction of a lake's trophic level using decay-resistant remains (diatom frustules and pigments) present in the sediment (Adams and Prentki, 1986; Lo Bianco, 1997; Musazzi, 2000; Bennion et al., 2000; Lotter, 2001). Furthermore, and regarding the chemical composition of the bottom sediments, many studies have stressed the relevance for analysing the sedimentary phosphorus (P) fractions to get some insights about the mechanisms involved in $\mathrm{CaCO}_{3}$ precipitation (i.e. de Vicente et al., 2006 and references there in).

Besides considering lake sediments as a historical record, sediments may also affect the water quality as a consequence of their dynamic and active character resulting from a great variety of biogeochemical reactions and transformations. In particular, it is in shallow lakes where this sediment-water interaction is extremely important for understanding the whole nutrient dynamics (i.e. Ryding, 1985; Boström et al., 1988).

For the case of $\mathrm{P}$, this internal loading has been identified as an important mechanism in delaying recovery of shallow lakes following reduced external P loading (Marsden, 1989; Sas, 1989; Ryding and Rast, 1992; Harper, 1992; Istvánovics and Somlyódy, 1999; Søndergaard et al., 1999; Schauser et al., 2003, among others). As Golterman (1995) established, the phosphate concentrations in the sediment and the overlying water are in a dynamic equilibrium where the position of this equilibrium, that controls whether input or output dominates, is determined by the interaction of multiple factors that may change over different time-scales.

We will synthesize some of the most relevant processes that could account for the dynamic sediment-water interactions characterizing shallow lakes.

Firstly, physical processes, such as resuspension of unconsolidated sediment, usually play a fundamental role in shallow lakes, where sediment often undergoes continuous wave action (i.e. Kristensen et al., 1992; Nõges et al., 1999; Weyhenmeyer and Blosech, 2001). Evidence for the importance of resuspension is plentiful (Kristensen et al., 1992; Evans, 1994; Bloesch, 1995; Weyhenmeyer et al., 1995; Golterman, 2004): Water quality in a lake is affected by reduced light penetration, which can ultimately promote biological changes, inducing a transition from a macrophyte-dominated community to a plankton-dominated one. Furthermore, nutrients recycling increases due to sedimentary nutrients (in particulate and dissolved forms) being brought back to the water column where, because of previously low phosphate levels, available $\mathrm{P}$ adsorbed to sediment particles could also be released and alter the lake's trophic status (Peters and Cattaneo, 1984). Nevertheless, the final effect of resuspension events on $\mathrm{P}$ availability depends on the particular properties of the lake's water (i.e. o-P concentration) and of the sediment (i.e. FeOOH:TP), being therefore to a certain extent lake specific (Søndergaard et al., 1992; de Vicente, 2004).

Apart from wind-induced resuspension, shallow lakes are also characterized by the fact that most of the organic matter produced in the water column, reach the sediment without being mineralised. Hence, it can be emphasized that sediments represent a crucial place for organic matter decomposition in these systems (Mann, 1982).

There is controversial evidence on the relative importance of microbial activity on aerobic P-release from the sediment. Evidence is 
mounting that microbial activity has a significant role in P-release (de Montigny and Prairie, 1993; Gächter and Meyer, 1993). Although many studies have been developed with an inappropriate P-fractionation methodology, the P-release from the sediment was shown to decrease in experiments were bacterial activity had been inactivated (Boers, 1986; Sinke and Cappenberg, 1988). The decomposition of organic matter in the sediment is a simple mechanism of o-P release that cannot be ruled out (de Montigny and Prairie, 1993). Qiu and McComb (1995) showed that the bacterial influence on P-release was mostly through their influence on the breakdown of org-P.

However there also exist many studies revealing that microbial activity causes an immobilization of sedimentary P. In those cases, Prelease is lower in non-sterilised (biotic and abiotic processes) than in sterilised samples (abiotic process) (Kamp-Nielsen, 1974; Doremus and Clesceri, 1982; Eckert et al., 1997; Clavero et al., 1999; Watts, 2000). A likely explanation for these controversial results is the different $\mathrm{P}$ limitation of bacterial activity. Then, when bacteria are $\mathrm{P}$ limited is likely to occur a $\mathrm{P}$ retention during organic matter mineralization, while they tend to release $\mathrm{P}$ when there is no a $\mathrm{P}$ limitation.

Another biologically mediated process that may account for the complexity of the sediment and water interactions typical of shallow lakes is the $\mathrm{P}$ translocation by some species of Cyanobacteria that live part of their life cycle in the sediment (i.e. Aphanizomenon, Gloeotrichia echinulata) (Osgood, 1988; Pettersson et al., 1993; Istvánovics et al., 2002). Furthermore, daily cycles production and respiration of benthic algae may affect both directly, through uptake and release of nutrients, and indirectly, by modifying redox potential, the nutrients exchange across the sediment-water interface (Carlton and Wetzel, 1988; Kelderman et al., 1988).

Lastly, radicular systems of the aquatic macrophytes add even more complexity to $\mathrm{P}$ exchange across sediment-water interface. By one hand, they can uptake dissolved nutrients from the pore-water (Carignan and Kalff, 1980;
Carignan, 1982; Barko and Smart, 1980, 1981; Carignan, 1985; Barko et al., 1991). By the other hand, they can also release $\mathrm{O}_{2}$ from the rhizome promoting the precipitation of $\mathrm{P}$ bound to FeOOH (Christensen and Andersen, 1996). Aquatic macrophytes may, moreover, indirectly affect sedimentary $\mathrm{P}$ dynamic by sediment stabilization and the subsequent resuspension reduction (i.e. James and Barko, 1990; Horppila and Nurminen, 2003).

Regarding chemical processes occurring at the sediment-water interface, their study has been traditionally focused on the Fe and P compounds' chemistry (Mortimer, 1941 in 1971). Nevertheless, recent studies have reviewed the redox-controlled $\mathrm{P}$ retention in lake sediments concluding that, apart from $\mathrm{O}_{2}$ availability, the $\mathrm{Fe}: \mathrm{P}$ ratio plays an outstanding role for $\mathrm{P}$ retention during aerobic conditions (Jensen et al., 1992; Gächter and Wehrli, 1998; Lehtoranta and Heiskanen, 2003; Gächter and Müller, 2003).

Since the classical view about sediment and water interactions was mainly focused on the abiotic redox-dependent fixation and release of $\mathrm{P}$, adsorption and desorption processes of $\mathrm{P}$ onto $\mathrm{CaCO}_{3}$ have been continuously underestimated. However, it has recently been outlined the relevance of the anaerobic $\mathrm{P}$ release in hard-water lakes, as a result of apatite dissolution occurring at low pH (Driscoll et al., 1993; Gómez et al., 1999; Golterman, 2001). The interactions between $\mathrm{P}$ and $\mathrm{Ca}$ compounds are of major interest for shallow lakes, due to their predominant eutrophic condition and usually high alkalinity, and also due to their quick water heating, both factors reducing $\mathrm{CaCO}_{3}$ solubility.

All in all, instability and extreme fluctuations in water quality characterizing shallow lakes may be to a large extent regulated by rapid changes in the internal rates of nutrient supply. In this context, the present study is based on a multi-approach perspective focused on both field measurements and laboratory experiments in order to determine the contribution of physical, biological and chemical mechanisms to nutrients' benthic dynamics in two shallow adjacent lakes. 


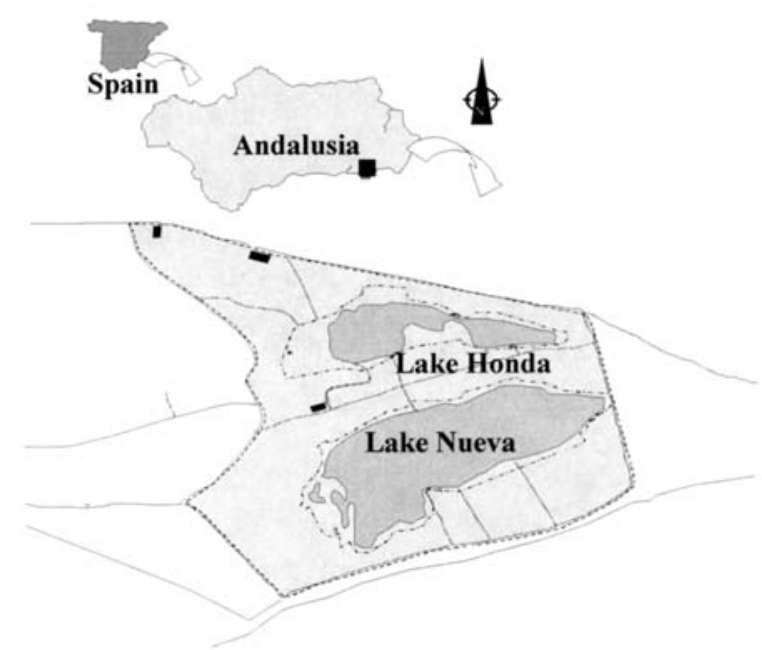

Figure 1. Location of the study lakes. Localización geográfica de las lagunas estudiadas.

\section{STUDY SITE}

The "Albufera de Adra" is the most important wetland located in south-eastern Spain (Fig. 1). It is composed of two shallow and eutrophic coastal lakes: Honda and Nueva. Because of the high biodiversity, an area of 230 ha surrounding both lakes was converted into a Natural Reserve (1989) and more recently (1994), Lake Honda and Lake Nueva have been included in the list of Protected Areas of the Ramsar Convention. Nevertheless, since the seventies, a steady process of land reclamation for agriculture (greenhouses) has resulted in an accelerated eutrophication process (Martinez-Vidal and Castro, 1990; Carrillo et al., 1996). During the last few years, both lakes have been deeply studied in the framework of a comprehensive Project ("Conservación de las Albu- feras de Adra"), partly financed by the UE-LIFE NATURE programme, which aims to insure that any water quality remedial measure is proposed on the basis of a thorough diagnosis and evaluation of the system (Cruz-Pizarro et al., 2002a).

A recent study has evidenced that although both study lakes show a notable temporal variability, in agreement with the unstable features of eutrophic systems (i.e. Barica, 1980; Dokulil and Teubner, 2003), Lake Honda is characterized by large longterm, seasonal and diel fluctuations in water quality (de Vicente et al., 2004) (Table 1).

Among the triggering mechanisms for the seasonal variability of Lake Honda, we can firstly remark the rapid changes in the external inputs and its high flushing rate (de Vicente et al., 2003). Because the hydrologic regime is dominated by surface water inputs (Benavente and Rodríguez, 2001; Benavente et al., 2003), Lake Honda can be considered as an epigenic and recharge wetland (González-Bernáldez, 1992). It explains its extreme high temporal variability through weather conditions and human activities on the drainage basin, and also its hypertrophic state as a result of the incoming of large amounts of allochthonous material from run-off (Cruz-Pizarro et al., 2002a,b; de Vicente et al., 2003; de Vicente and Cruz-Pizarro, 2003). By contrast, Lake Nueva can be classified as a hypogenic and discharge wetland where the predominant entry of groundwater plays an important role in buffering most wetland characteristics and in increasing its temporal stability.

In the present study, we hypothesize that, apart from external forcing (i.e. weather and watershed processes), the noteworthy unpredic-

Table 1. Inter-annual variability in water transparency $\left(\mathrm{Z}_{\mathrm{SD}}\right)$, Chl- $a$, o-P, TP and TN concentrations (modified from de Vicente, 2004). Mean (Min-Max). Variabilidad interanual en la transparencia del agua $\left(Z_{S D}\right)$ y concentraciones de Chl-a, o-P, TP y TN (modificado de de Vicente, 2004).

\begin{tabular}{|c|c|c|c|c|}
\hline & \multicolumn{2}{|c|}{ Lake Honda } & \multicolumn{2}{|c|}{ Lake Nueva } \\
\hline & 1999-2000 & 2000-2001 & 1999-2000 & 2000-2001 \\
\hline $0-P\left(\mu \mathrm{g} \mathrm{l}^{-1}\right)$ & $40(2-210)$ & $77(0-275)$ & $7(0-32)$ & $4(0-24)$ \\
\hline $\mathrm{TP}\left(\mu \mathrm{g} \mathrm{l}^{-1}\right)$ & $255(112-425)$ & $295(146-471)$ & $79(25-147)$ & $99(24-155)$ \\
\hline$T N\left(\mathrm{mg} \mathrm{l}^{-1}\right)$ & $2.94(1.57-5.59)$ & $3.86(0.99-7.14)$ & $1.10(0.80-1.67)$ & $1.68(1.16-2.00)$ \\
\hline Chl- $a\left(\mu \mathrm{g} \mathrm{l}^{-1}\right)$ & $160(57-396)$ & $129(4-292)$ & $57(7-126)$ & $54(8-125)$ \\
\hline $\mathrm{Z}_{\mathrm{SD}}(\mathrm{cm})$ & $34(20-50)$ & $64(10-250)$ & $119(70-210)$ & $75(30-140)$ \\
\hline
\end{tabular}


tability observed in the nutrients' dynamic of Lake Honda compared to Lake Nueva (de Vicente et al., 2003; de Vicente, 2004) is the result of the specially intense physical (resuspension), chemical (oxidation vs. reduction), and biological (i.e. organic matter mineralization) processes, occurring at the sediment-water interface of this hypertrophic lake.

\section{MATERIAL AND METHODS}

\section{Meteorological and morphometric data}

Daily wind-speed data were gathered from a meteorological station at the experimental station "Las Palmerillas", located in El Ejido, the closest town to the lake area (less than $5 \mathrm{~km}$ ).

Hypsographic curves and morphometric variables were based on the bathymetric map (Cruz-Pizarro et al., 1992).

Hydrological regime is described in detail in de Vicente, 2004).

\section{Water Column Monitoring}

A fortnightly monitoring of Lake Honda and Lake Nueva was conducted from August 1999 to August 2001. From a sampling station located at the maximum depth site of each lake,

Table 2. Abbreviations used in the text. Abreviaciones usadas en el texto.

$\begin{array}{ll}\mathrm{CaCO}_{3} \approx \mathrm{P} & \text { calcium bound phosphate } \\ \mathrm{Fe}(\mathrm{OOH}) \approx \mathrm{P} & \text { iron bound phosphate } \\ \mathrm{Fe}(\mathrm{OOH}) & \text { ferric oxyhydroxides } \\ \text { org-P } \rightarrow \text { acid } & \text { acid soluble organic phosphate } \\ \text { org-P } \rightarrow \text { alkali } & \text { hot NaOH soluble organic phosphate } \\ \text { org- } \mathrm{P}_{\text {residual }} & \text { residual organic phosphate } \\ \text { org-P } & \text { organic P } \\ \text { inorg-P } & \text { inorganic P } \\ \text { TP } & \text { total P } \\ \text { TN } & \text { total N } \\ \text { TC } & \text { total C } \\ \text { o-P } & \text { ortho-phosphate; } \\ \text { org-C } & \text { dissolved organic C } \\ \text { inorg-C } & \text { dissolved inorganic C } \\ \text { C.F.U. } & \text { Colony Formation Units }\end{array}$

lake-water samples were collected using a Van Dorn sampler at three different depths in the vertical profile (surface, mid-depth and bottom). Once at the laboratory, total phosphorus (TP) and total nitrogen (TN) were directly measured from non-filtered water (APHA, 1995). A sub-sample was filtered for the analysis of inorg- and org- $\mathrm{C}_{\mathrm{dis}}$ concentrations using a TC Autoanalyser (Dohrman, DC-190).

\section{Sediment Monitoring}

\section{Chemical analyses}

Surface sediment samples $(0-5 \mathrm{~cm})$ were collected monthly, from July 2000 to August 2001, at the deepest site of each lake, using an Ekman dredge. Within 24 hours, the interstitial water was separated from the sediment particles by centrifugation at 5000 r.p.m. during $10 \mathrm{~min}$. (Enell and Löfgren, 1988). The supernatants were then filtered through Whatman GF/C filters. The wet sediments were kept at $4^{\circ} \mathrm{C}$ until they were fractionated 1-2 weeks later. No treatment (drying, freezing or sieving) was performed on the sediment samples before fractionation.

The concentration of TN and TP were quantified in the non-filtered interstitial water (APHA, 1995). A sub-sample was filtered for o-P quantification as molybdate reactive phosphorus (Murphy and Riley, 1962), the inorgand org- $\mathrm{C}_{\text {diss }}$ using a TC Autoanalyser (Dohrman, DC-190) and Ammonium $\left(\mathrm{NH}_{4}{ }^{+}\right)$ concentration following Rodier (1989).

Sediment was analysed for TC and TN determination with a $\mathrm{CNH}$ Elemental Analyser. The P-fractionation in the sediment was performed following the EDTA method, based on a sequential extraction with chelating compounds (Golterman, 1996), (Table 2).

\section{Physical properties}

The granulometric composition of the surface sediment layer was determined using the method proposed by Robinson (1922), basically based on the Stokes law. 


\section{Biological activity}

Contribution of biotic vs. abiotic processes on $\mathrm{P}$ sedimentary recycling

For the continuous-flow experiment, $250 \mathrm{ml}$ of $\mathrm{H}_{2} \mathrm{O}$ were added to a set of 5 beakers $(10 \mathrm{~cm}$ diameter; $500 \mathrm{ml}$ capacity) each containing $35 \mathrm{~g}$ of fresh sediment $(1 \mathrm{~cm}$ sediment layer) collected from Lake Honda and Lake Nueva in July and August 2001, respectively (Serrano et al., 2005). Three beakers were autoclaved $\left(120^{\circ} \mathrm{C}\right.$, $20 \mathrm{~min}$ ) following Clavero et al. (1999) and two others were kept as controls. Continuous flow system consisted of incubating each beaker with a continuous input of $\mathrm{H}_{2} \mathrm{O}$ (controls) and $\mathrm{H}_{2} \mathrm{O}+$ $1 \% \mathrm{ClCH}_{3}$ (sterilised treatments), controlled by electrical pumps. In order to maintain a constant water volume inside the beaker $(250 \mathrm{ml})$, output flow was exactly the same as input $(1 \mathrm{ml} \mathrm{min}-1)$. The water from the outlet, collected in PET bottles, was kept for $\mathrm{pH}$ determination and for o-P concentration (Murphy and Riley, 1962). Conditions for incubation were darkness and an average temperature of $30^{\circ} \mathrm{C}$.

\section{Sediment respiratory activity}

Electron Transport System Activity (ETSA) was determined at the sediment top layer ( $0-5$ $\mathrm{cm})$ at the deepest site of each lake, from February to November 2002. ETSA was measured by using the method proposed by Broberg (1985) with slight modifications. In principle, this method is based on the biological reduction of the tetrazolium salts to their respective tetrazolium formazan by sediment microorganisms. The formazan produced can then be used as a measure of the ETSA in the sediment. For measuring ETSA in the study lakes, 2-3 grams of wet sediment was mixed with $10 \mathrm{ml}$ of homogenisation buffer $\left(\mathrm{MgSO}_{4} \cdot 7 \mathrm{H}_{2} \mathrm{O}\right.$, PVP, Triton and EDTA) and sonicated in an ice bath for $4 \mathrm{~min}$ $\left(0^{\circ} \mathrm{C}\right)$. The mixture was clarified by centrifuging it at $10.000 \mathrm{rpm}$ for $10 \mathrm{~min}\left(0^{\circ} \mathrm{C}\right)$. Then, we mixed $0.5 \mathrm{ml}$ of the supernatant with $1 \mathrm{ml}$ of substrate solution (NADH, NADPH and Nasuccinate), $0.5 \mathrm{ml}$ of INT (2-( $p$-iodophenil-)-3( $p$-nitrophenol)-5 phenil tetrazolium chloride) and $0.5 \mathrm{ml}$ of the homogenisation buffer. The mixture was incubated at the same temperature measured in the field $\left(15-28^{\circ} \mathrm{C}\right)$ for $20-30 \mathrm{~min}$, depending on the temperature. Immediately after time incubation, the addition of Quench (phosphoric acid and formaldehyde in 1:1 proportion) was carried out in order to stop the reaction. Absorbance of the sample at $490 \mathrm{~nm}$ was read with a spectrophotometer. In calculating ETSA, the molar adsorption coefficient of INT-formazan of 1.42 (Kenner and Ahmed, 1975) was used. All ETSA values were determined within 24 hours of field sampling. For optimising the method, a set of preliminary experiments were performed in order to determine the amount of wet sediment, homogenisation conditions (method, time and homogenisation solution) and also to establish the sufficient concentration of substrates to achieve $\mathrm{V}_{\max }$ of the INT reduction (de Vicente, 2004).

In addition, Chl- $a$, Phaeopigments, Colony Formation Units (CFU) of anaerobic and aerobic bacteria, and Organic Matter (O.M.) content were determined at the surface sediment. All of these methods are thoroughly described in de Vicente (2004).

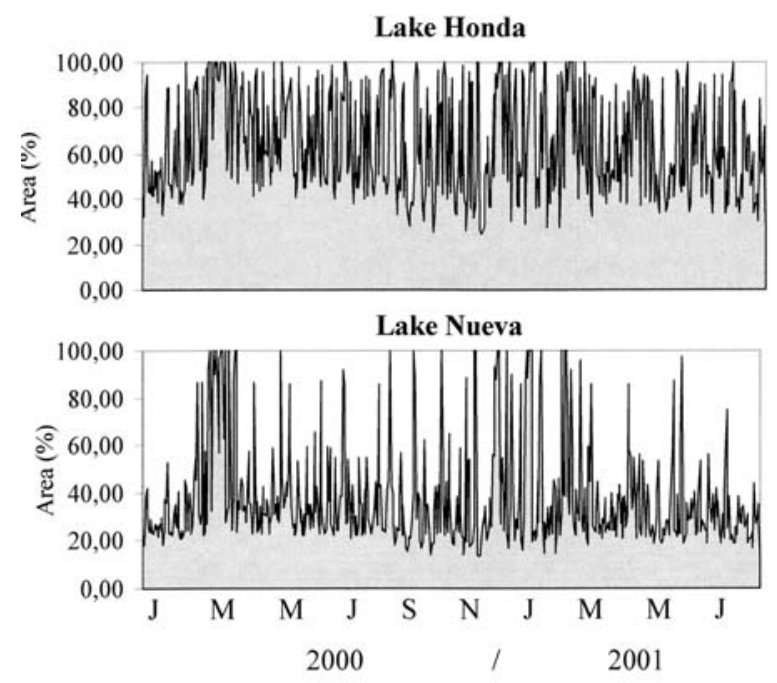

Figure 2. Estimated value for the wave height $(\mathrm{m})$ and estimated lake area (\%) that is affected by waves (from de Vicente, 2004). Valor estimado de la altura (m) de la onda generada por el viento y del área (\%) del lago afectada por las olas (tomado de de Vicente, 2004). 


\section{Sedimentation rates}

A pair of sediment traps, Plexiglas cylinders with an aspect ratio higher than 6 (Bloesch and Burns, 1980), were set at three different layers $(50,135$ and $260 \mathrm{~cm})$ at the deepest site of each lake. The particulate matter collected in the traps, every two weeks (February 2000-August $2001)$, was dried $\left(60^{\circ} \mathrm{C}\right.$ for $\left.24 \mathrm{~h}\right)$ and weighed, to quantify settling fluxes $\left(\mathrm{g}\right.$ d.w. $\left.\mathrm{m}^{-2} \mathrm{~d}^{-1}\right)$. The settled material was also analysed for TC, TN and TP using the method described above.

\section{Achieving the impact of sediment resuspension}

Model to predict resuspension events

Following Carper and Bachman (1984), wave period $(T, \mathrm{~s})$ has been estimated as a function of wind speed $\left(V, \mathrm{~m} \mathrm{~s}^{-1}\right)$ and of the effective distance over water that the wind blows (fetch, $F, \mathrm{~m})$, by the equation:

$$
\frac{g T}{2 \pi V}=1.20 \tanh \left[0.077\left(\frac{g F}{V^{2}}\right)\right]
$$

Thus, wavelength $(L, \mathrm{~m})$ is related to its period $(T)$ by the equation:

$$
L=\frac{g T^{2}}{2 \pi}
$$

where $g$ is the gravitational constant $\left(9.8 \mathrm{~m} \mathrm{~s}^{-2}\right)$.

Wave height is then calculated as one-half of the wavelength. It can be assumed that windinduced waves touch the bottom when the water depth is less than a half of its wavelength (Carper and Bachmann, 1984).

\section{Adsorption experiments}

The flocculent layer was sampled in November 2002 at the maximum depth station in each lake, using a horizontal Van Dorn sampler, which was bounced off the bottom a few times to resuspend the sediment (Doremus and Clesceri, 1982). In the laboratory, the flocculent layer was concentrated by centrifugation (10 min, $10000 \mathrm{rpm})$ and $\mathrm{P}$ adsorption experiments were carried out using the batch-experimental technique. Spe-
Table 3. Main morphometric and hydrological features of the studied lakes (July 1999-August 2001). ${ }^{1}$ de Vicente et al. (2003). Principales características morfométricas e hidrológicas de las lagunas estudiadas (Julio de 1999-Agosto de 2001). Ide Vicente et al. (2003).

\begin{tabular}{lcc}
\hline & Lake Honda & Lake Nueva \\
\hline Lake area $(\mathrm{A})\left(\mathrm{m}^{2}, 10^{3}\right)$ & 80.1 & 260.4 \\
Maximum lenght $(\mathrm{m})$ & 586 & 759 \\
Shoreline lenght $\left(\mathrm{m}, 10^{2}\right)$ & 14.66 & 20.66 \\
Maximum depth $\left(\mathrm{Z}_{\text {max }}\right)(\mathrm{m})$ & 3.19 & 3.80 \\
Volume $\left(\mathrm{m}^{3}, 10^{3}\right)$ & 91.52 & 594.70 \\
Catchment area $\left(\mathrm{A}_{\mathrm{c}}\right)\left(\mathrm{m}^{2}, 10^{5}\right)$ & 137.2 & 5.0 \\
Mean depth $(\bar{Z})(\mathrm{m})$ & 1.14 & 2.28 \\
Relative depth $(\mathrm{m})$ & 1.00 & 0.66 \\
Shore development & 1.46 & 1.14 \\
$\mathrm{Z}_{\mathrm{m}}: \mathrm{Z}_{\text {max }}$ & 0.36 & 0.60 \\
$\mathrm{~A}_{\mathrm{c}}: \mathrm{A}$ & 171.30 & 1.92 \\
Dynamic ratio $(\sqrt{\mathrm{A}} / \bar{Z})$ & 253 & 223 \\
Residence time $(\mathrm{yr})$ & 0.17 & 2.95 \\
External Areal loading $^{1}$ & 1.73 & 0.03 \\
g P m $\left.^{-2} \mathrm{yr}^{-1}\right)^{1}$ & & \\
\hline
\end{tabular}

cific details about these experiments are provided in de Vicente (2004) and de Vicente (2004).

\section{Statistical analysis}

Statistical analysis was performed using StatSoft, Inc. (2001). For t-student test, unless otherwise stated, the significance level was established at $\mathrm{p}<0.05$.

\section{Results and discussion}

Although both study lakes show a notable temporal variability, Lake Honda is characterized by large long-term, seasonal and diel water quality fluctuations (de Vicente, 2004). Instability and extreme fluctuations in Lake Honda water quality are to a large extent regulated by rapid changes in the internal rates of nutrient supply as a result of intense biological, physical, and chemical mechanisms at the sediment-water interface.

\section{Physical forcing of water quality}

Some of the most important morphometric features of both lakes are summarised in Table 3 . 


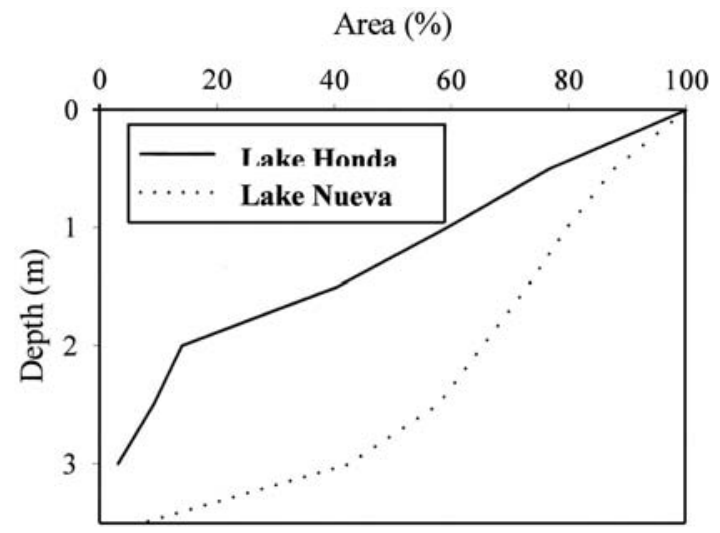

Figure 3. Areal hypsographic curves. Curvas hipsográficas de superficie.

Table 4. Results of the adsorption experiment with the floculent layer (from de Vicente, 2004). Resultados del experimento de adsorción con el sedimento resuspendido (tomado de de Vicente, 2004)

\begin{tabular}{lcc}
\hline & $\mathbf{P}_{\text {initial }}\left(\boldsymbol{\mu g} \mathrm{P} \mathrm{PO}_{\mathbf{4}}{ }^{-\mathbf{3}} \mathrm{I}^{\mathbf{- 1}}\right)$ & $\mathbf{P}_{\text {ads }}\left(\boldsymbol{\mu g ~ g ^ { - 1 }}\right.$ d.w. $)$ \\
\hline Honda & 37 & -22 \\
Nueva & 4 & +4 \\
\hline
\end{tabular}

The higher values reported for the dynamic ratio, a measure for bottom dynamics (Håkanson and Jansson, 1983), in Lake Honda might suggest that resuspension may play a relatively major role in this lake compared to Lake Nueva. Similarly, the application of the empirical model showed that the impact of sediment resuspension is higher in the former lake than in the later one. In particular, as figure 2 shows, more than half of the lake area was affected by waves in $80 \%$ of the wind events in Lake Honda and only in $25 \%$ in Lake Nueva.

The present study highlights that, apart from extrinsic factors (wind velocity), sediment resuspension depends on lake morphometry and sediment properties, factors that cause Lake Honda to be much more affected than Lake Nueva by resuspension events. Thus, while in Lake Honda a great proportion of sediment is located at relatively low depth (Fig. 3), sediment of the more recent Lake Nueva is less subjected to windinduced turbulence, and sediment resuspension is also ultimately limited by the relevant contribution of the sand-to-mineral matrix (Fig. 4).

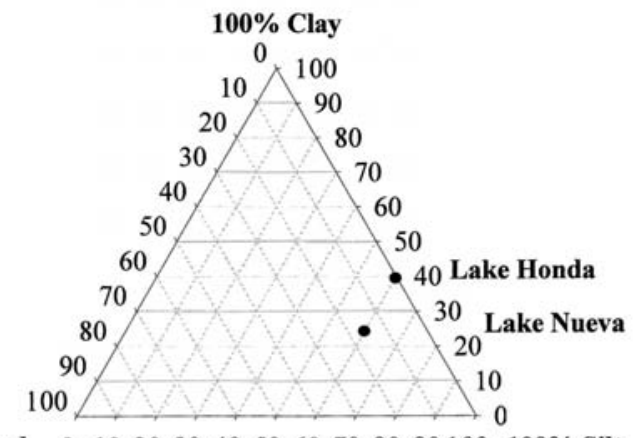

$100 \%$ Sand $\quad 0 \quad 10203040506070 \quad 8090100 \quad 100 \%$ Silt

Figure 4. Granulometric composition of the surface sediment. Composición granulométrica del sedimento superficial.

Table 5. Some of the biological variables measured at the surface sediment. Mean (SD). ( $\mathrm{n}=7)$. Algunas de las variables biológicas medidas en la superficie del sedimento. Media (SD) $(n=7)$.

Lake Honda Lake Nueva

\begin{tabular}{lcc}
\hline ETSA $\left(\mu \mathrm{l} \mathrm{O}_{2} \mathrm{~g}^{-1}\right.$ d.w. $\left.\mathrm{h}^{-1}\right)$ & $50.1(15.7)$ & $63.6(48.6)$ \\
O.M. $(\%)$ & $8.6(1.9)$ & $16.65(1.4)$ \\
Phaeopigments $\left(\mu \mathrm{g} \mathrm{g}^{-1}\right.$ d.w. $)$ & $103.5(3.5)$ & $101.33(19.9)$ \\
Chl- $a\left(\mu \mathrm{g} \mathrm{g}^{-1}\right.$ d.w. $)$ & $41.1(8.8)$ & $68.5(29.8)$ \\
Anaer. Bacteria $(\log$ C.F.U./g dw. $)$ & $6.55(0.50)$ & $6.15(0.42)$ \\
Aer. Bacteria $(\log$ C.F.U./g dw. $)$ & $7.41(0.18)$ & $7.00(0.25)$ \\
ETSA:OM & $5.9(1.9)$ & $3.8(2.7)$
\end{tabular}

Finally, the impact of sediment resuspension has also been examined simulating the effect of lake water enrichment in resuspended material. Our results have shown that while the flocculent layer tends to release phosphate to the water column in Lake Nueva, resuspension causes a phosphate removal from the water column in Lake Honda. Such patterns are a consequence of the large differences in the o-P concentrations in the two study lakes (Table 4).

Additionally, we may outline the feedback relationship between resuspension and light climate in both lakes. In Lake Honda, resuspension events increase the total suspended solids, thereby attenuating light and limiting the development of macrophytes and benthic algae, which would otherwise aid sediment stabilization. By contrast, resuspension in Lake Nueva is also limited by the presence of cohesive agents in the sediment such as algal mats and submerged macrophytes, their growth being encouraged by the strong light penetration (Cruz-Pizarro et al., 2002a). 
As de Vicente (2004) have suggested, several facts indicate that resuspension plays a greater role in Lake Honda than in Lake Nueva. Firstly, the C:P ratio is similar in the surface sediment than in the material collected by the bottom sedimentation traps in Lake Honda, while Lake Nueva shows major differences between chemical composition of the two materials. Secondly, organic-matter concentrations in the surface sediment from the hypertrophic Lake Honda are far lower than in Lake Nueva (Table 5), presumably because of the dynamic transport of sedimentary particulate organic matter to the water column, which would stimulate its overall mineralization, in the way some recent studies have also suggested (Wainright and Hopkinson, 1997).

\section{Biological activity at the surface sediment}

\section{Biotic vs. abiotic P release}

In Lake Nueva, the sediment retained o-P and there were no significant differences between poisoned and non-poisoned treatments (Fig. 5).
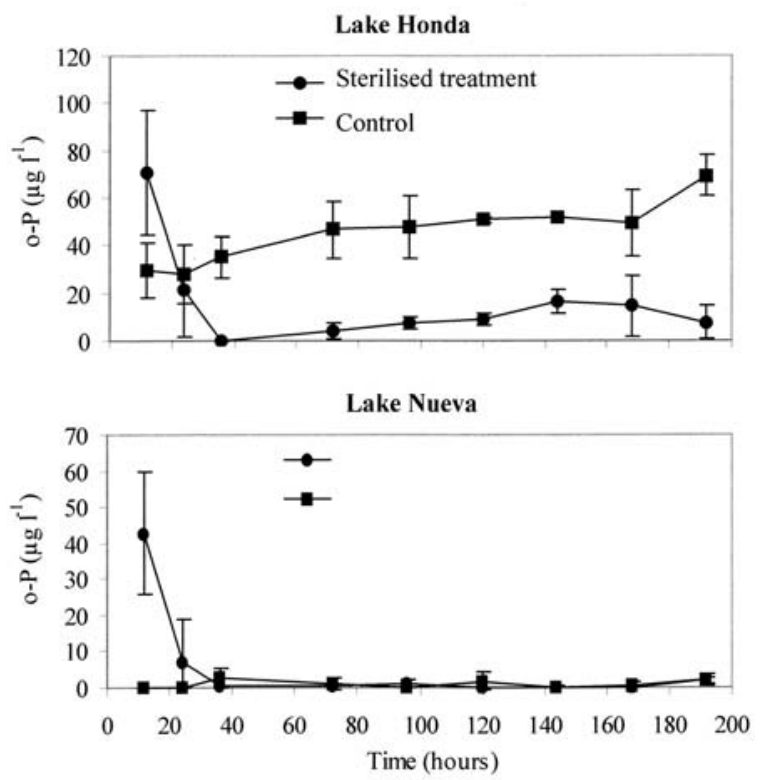

Figure 5. Variation in time of o-P concentrations in the water from control and sterilised treatment (modified from Serrano et al., 2005). Variación de la concentración de o-P presente en el agua del control y del tratamiento esterilizado (modificado de Serrano et al., 2005).
Sediment from Lake Honda by contrast, showed very high $\mathrm{P}$ release rates in the control compared to the sterilised treatment. In this lake, abiotic mechanisms may play a secondary role, while biotic ones mainly control sedimentary phosphate mobilization. These results would hence confirm the temperature-dependence of o-P release rates that has been previously reported by de Vicente (2004). Actually, the impact of biotic activity on o-P release could be both direct by hydrolysing organic $\mathrm{P}$, and indirect, by lowering the redox potential in the surface sediment which ultimately may induce release of $\mathrm{Fe}(\mathrm{OOH}) \approx \mathrm{P}$, a $\mathrm{P}$-fraction that presents a large pool in the sediment of Lake Honda (Table 6). The relevance of biologically mediated aerobic o-P release, as stimulated by raised temperatures, was shown by Jensen and Andersen (1992), who found a notable reduction in the thickness of the oxidized surface layer and a subsequent increased in $\mathrm{P}$ release rates when temperature was raised.

Differences observed in aerobic P-release from the sediment of both studied lakes are likely to be explained by differences in organic matter quality. De Vicente et al. (2003) showed that although the sestonic material had a similar concentration of TP in both lakes, the average $\mathrm{C}: \mathrm{P}$ ratio was higher in Lake Honda than in Lake Nueva. However, the biodegradability of the top sediment was lower in Lake Nueva as the C:P ratio of the top sediment was significantly higher in this lake. Then, it is likely that the top sediment of Lake Nueva had a different source of organic matter, and hence $\mathrm{C}$, that increased the $\mathrm{C}: \mathrm{P}$ ratio. In this sense, the concentration of planktonic chlorophyll $a$ was higher in Lake Honda, while the lower turbidity of the water in Lake Nueva favoured the growth of submersed macrophytes in the littoral area during spring and summer (Cruz-Pizarro et al., 2002b). As it is well known phytoplankton detritus is easily degradable, while vascular plants remains are structurally complex and their degradation is slower (Kristensen et al., 1995). Therefore, the presence of vascular plants that grew on the sediments could have accounted for the higher $\mathrm{C}: \mathrm{P}$ ratio in the top sediment of Lake Nueva. This could cause a lower mineralization rate and 
Table 6. P-fractions at the surface sediment ( $\mu \mathrm{g} \mathrm{g}^{-1}$ d.w.) $(\mathrm{n}=12)$. Fracciones de $P$ en sedimento superficial $\left(\mu g g^{-1}\right.$ d.w.) $(n=12)$.

\begin{tabular}{lcc}
\hline & Honda & Nueva \\
\hline $\mathrm{Fe}(\mathrm{OOH}) \approx \mathrm{P}$ & 135 & 18 \\
$\mathrm{CaCO}_{3} \approx \mathrm{P}$ & 313 & 142 \\
Org-P $\rightarrow$ acid & 61 & 53 \\
Org-P $\rightarrow$ alkali $_{\text {Org-P }_{\text {residual }}}$ & 174 & 166 \\
$\sum \mathrm{P}_{\text {sed }}$ & 11 & 14 \\
Inorg-P:Org-P & 694 & 393 \\
FeOOH (mg Fe g-1 d.w.) & 1.82 & 0.68 \\
FeOOH:TP (atomic ratio) & 15.6 & 5.2 \\
& 15 & 5 \\
\hline
\end{tabular}

thereby leave a higher concentration of organic matter and org-P in the surface sediment as compared to Lake Honda. We suggest that the relative importance of planktonic (phytoplankton) and benthic (macrophytes) primary producers can explain the differences observed in the P-recycling and sediment-P composition of both lakes.

\section{Sediment respiratory activity}

ETSA was higher in Lake Nueva than in Lake Honda (Table 5). Seasonal variation of ETSA was especially important for the case of Lake Nueva, reflected by the extremely high values of SD.

Contrary to Relexans (1996), who found that the ETSA provided a good estimate of bacterial activity, our results have shown a weak relation between aerobic and anaerobic bacteria and ETSA. One likely explanation may be that, as Trevors (1984) suggested, the number of viable microbial cells in the sediment is much lower than the number of total cells. Moreover, ETSA is the result of the activity of both intra and extracellular enzymes, being these ones able to remain active for several days or even weeks (Trevors, 1984; Tóth, 1992; 1994).

In the present study, among all analysed variables that may affect the ETSA (bacterial and algal biomass; organic matter concentration), we have recognized a large contribution of phytobenthos, especially in Lake Nueva. The relevance of this community for the whole lake metabolism was already stated by Tóth (1992), who found that a great proportion of the total primary production in Lake Balaton was comprised by benthic primary production.

Furthermore, and contrarily to what was expected, there was no relation in the sediment of the studied lakes between the seasonality in organic matter content and ETSA within a single lake. This lack of relation may be due to the fact that benthic community does not respond immediately to organic matter inputs but it requires a time lag that ultimately depends on the organic matter nature (Newrkla, 1982; Sommaruga, 1991).

Finally, and following Relexans et al. (1992), we have estimated the ETSA:O.M. ratio as a useful indicator of organic carbon quality. The significantly higher values in Lake Honda compared to Lake Nueva corroborate the already mentioned biodegradable and refractory nature of the settled material of Lake Honda and Nueva, respectively.

\section{Chemical monitoring at the sediment-water interface}

Although settling fluxes of TC and TN were much higher in Lake Honda, its sediment showed lower concentrations than that of Lake Nueva (Fig. 6). These results together with the huge nutrient concentrations $\left(\mathrm{o}-\mathrm{P}, \mathrm{NH}_{4}{ }^{+}\right.$and inorg- and org- $\left.\mathrm{C}_{\text {dis }}\right)$ measured in the interstitial water in Lake Honda again suggest a fast nutrient recycling in this lake. By contrast, the majority of nutrients in Lake Nueva sediment are in particulate forms, being slowly mobilized to the dissolved pool.

In fact, we could relate the organic matter degradability with the ratio between the decomposition products (nutrients in the pore-water) and their sources (nutrients in the solid phase). Hence, the much higher values recorded for org$\mathrm{C}_{\text {dis }}$ :O.M., $\mathrm{NH}_{4}{ }^{+}$:TN and o-P:TP in the sediment of Lake Honda compared to Lake Nueva, support the idea of a labile organic settled matter (planktonic) in Lake Honda and a structurally more complex organic matter in Lake Nueva. Likewise, the much higher value for the ratio between inorganic and organic phosphate in the sediment from Lake Honda with respect to Lake Nueva once more confirms those statements. 

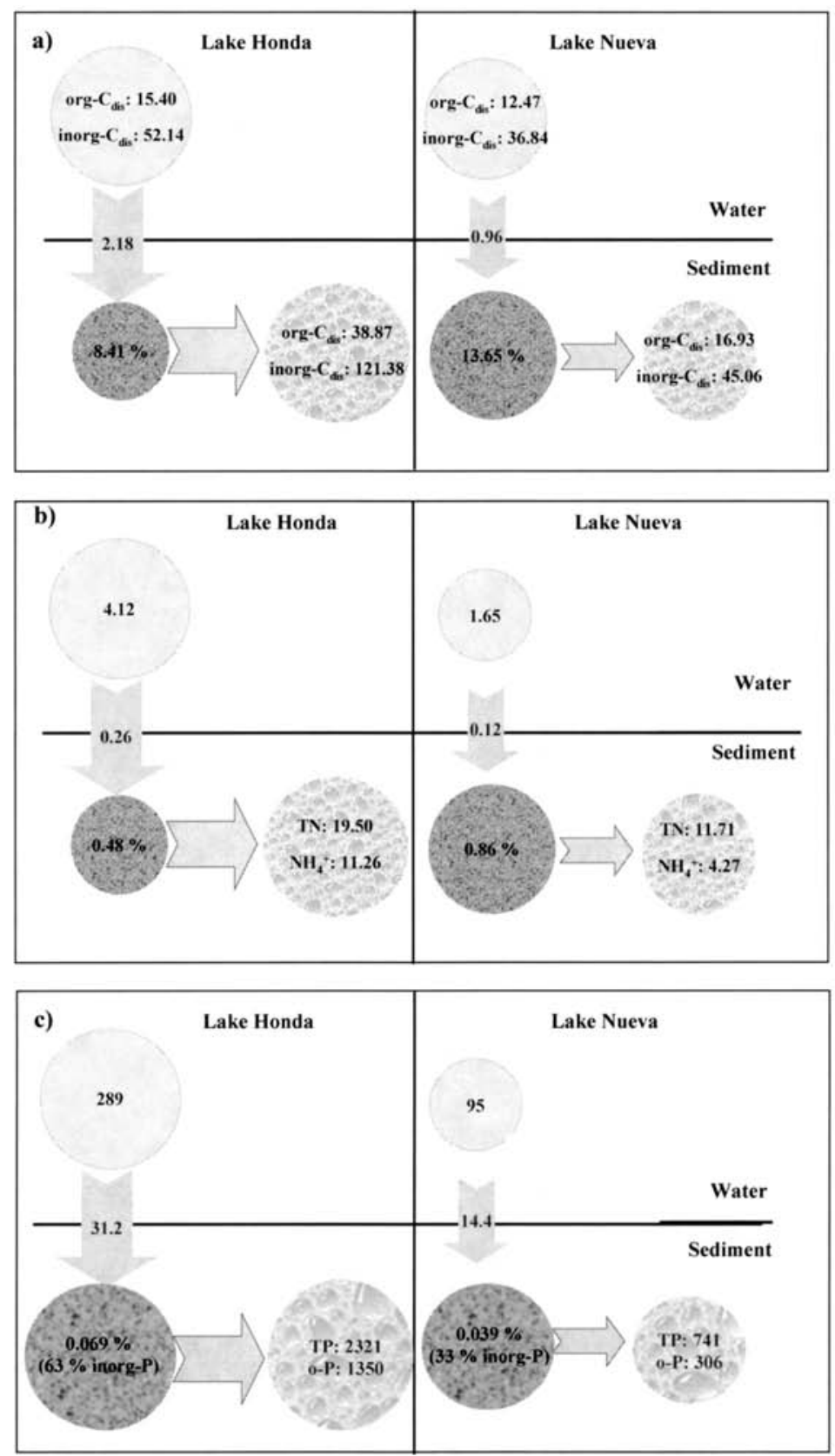

Figure 6. $\mathrm{C}(\mathrm{a}), \mathrm{N}(\mathrm{b})$ and $\mathrm{P}$ (c) regeneration at the sediment and water interface. Units: liquid phase: $\mathrm{mg}(\mathrm{C}$ or $\mathrm{N}) 1^{-1}$ and $\mu \mathrm{g} \mathrm{P}^{-1}$; solid phase: \% $(\mathrm{C}, \mathrm{N}$ or $\mathrm{P})$; settling rates: $\mathrm{g}(\mathrm{C}$ or $\mathrm{N}) \mathrm{m}^{-2} \mathrm{~d}^{-1}$ and $\mathrm{mg} \mathrm{P} \mathrm{m} \mathrm{m}^{-2} \mathrm{~d}^{-1}$. All figures are referred to annual average concentrations of TC, TN or TP, unless otherwise stated. Regeneración de $C$ (a), $N$ (b) y $P$ (c) en la interfase agua-sedimento. Unidades: fase líquida: $m g$ (C o N) $l^{-1}$ y $\mu \mathrm{g} P l^{-1}$; fase sólida: \% (C, No P); tasa de sediemntación: $g(C$ or $N) m^{-2} d^{-1} y m P m^{-2} d^{-1}$. Todos los datos se refieren a la concentración media anual de TC, TN o TP, al menos que se especifique lo contrario.

Regarding to the inorganic $\mathrm{P}$ pools $(\mathrm{FeOOH} \approx \mathrm{P}$ and $\mathrm{CaCO}_{3} \approx \mathrm{P}$ ), figure 7 shows that the distribution of each fraction ultimately depends on the amount of added $\mathrm{P}$, depth of the water column, $\mathrm{pH}, \mathrm{Ca}^{+2}$ concentration in the lake water, and $\mathrm{FeOOH}$ concentration in the sediment (Golterman, 1998). This diagram and the results obtained for Lake Honda suggest that 
the much higher concentrations of $\mathrm{Fe}(\mathrm{OOH}) \approx \mathrm{P}$ compared to Lake Nueva are the result of a much higher availability of $\mathrm{FeOOH}$ in the former lake (Table 6). Moreover, and although o-P concentration in the pore-water increases as $\mathrm{Fe}(\mathrm{OOH}) \approx \mathrm{P}$ is forming, the lower $\mathrm{Ca}^{+2}$ concentration in Lake Honda delays $\mathrm{CaCO}_{3} \approx \mathrm{P}$ precipitation. In Lake Nueva, by contrast, the high values for interstitial water $\mathrm{Ca}^{+2}$ concentrations and the lower values for oxyhydroxides in its sediment limit the presence of $\mathrm{Fe}(\mathrm{OOH}) \approx \mathrm{P}$.

If we finally compare the TN concentration in both study lakes, and also consider that accordingly to Martinova (1993) and Golterman (2004) more than $90 \%$ of TN is present as orga- nic $\mathrm{N}$, we could assume that ammonification of organically bound $\mathrm{N}$ represents a key process for losing $\mathrm{N}$ from the sediment of Lake Honda. By contrast, in Lake Nueva, macrophytes patches and the presence of $\mathrm{N}_{2}$-fixing Cyanobacteria may account for an additional $\mathrm{N}$ input to the sediment.

\section{SYNTHESIS}

Strong differences between the two studied systems have been revealed. In Lake Honda, high in-lake nutrient concentrations, which ultimately support a large algal biomass, are basically maintained by: $i$. Sediment resuspension
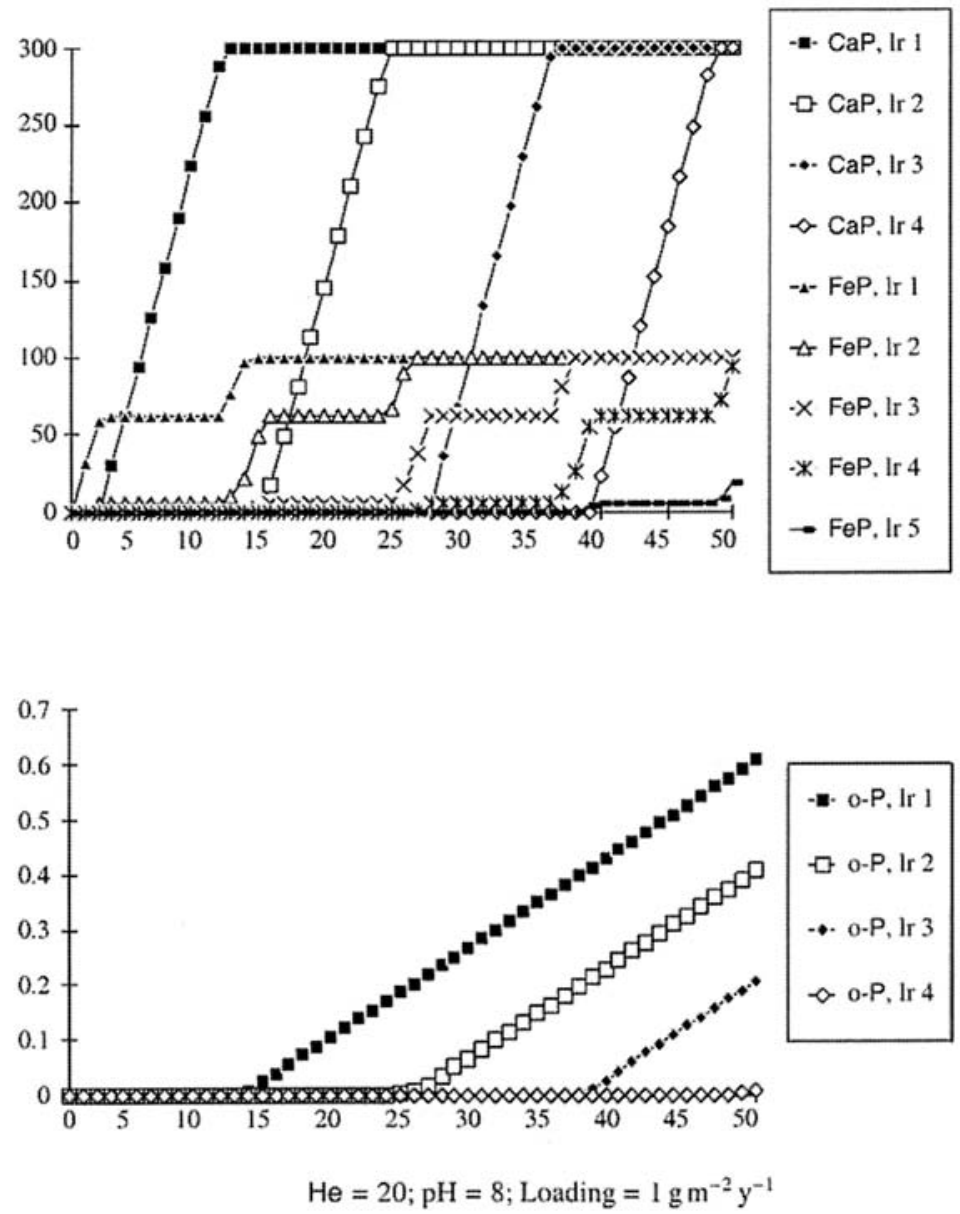

Figure 7. Concentrations of o-P, $\mathrm{FeOOH} \approx \mathrm{P}, \mathrm{CaCO}_{3} \approx \mathrm{P}\left(\mathrm{mmol} \mathrm{m}^{-2}\right)$ in the successive sedimentary layers $(\mathrm{lr})$ in a lake $(2 \mathrm{~m}$ depth), as a function of the cumulative $\mathrm{P}$ load $\left(\mathrm{g} \mathrm{m}^{-2}\right) \cdot \mathrm{pH}=8 ; \mathrm{Ca}^{+2}=40 \mathrm{mg} \mathrm{l}^{-1}$ (Golterman, 2004). Concentraciones de o-P, FeOOH $\approx P$, $\mathrm{CaCO}_{3} \approx P\left(\mathrm{mmol} \mathrm{m} \mathrm{m}^{-2}\right.$ en los sucesivos estratos del sedimento (lr) en un lago de $2 \mathrm{~m}$ de profundidad, en función de la carga de $P$ acumulada $\left(\mathrm{g} \mathrm{m}^{-2}\right) \cdot \mathrm{pH}=8 ; \mathrm{Ca}^{+2}=40 \mathrm{mg} \mathrm{l}^{-1}$ (Golterman, 2004). 
that is favoured by its morphometry, hydrologic regime and sediment granulometry. ii. Intense organic matter mineralization due to the labile nature of the organic settled matter (planktonic).

In Lake Nueva, physical constrains (i.e. windinduced resuspension) have a limited effect due to the coarse surface sediment and to the development of macrophyte patches (Najas marina, Potamogeton pectinatus). In addition, the structurally more complex organic matter of its sediment regulates the low nutrients turnover. In this lake, nutrient exchange rates across the sediment-water interface are also controlled by the chemical equilibrium between the solid and the liquid phase, such as $\mathrm{P}$ adsorption onto $\mathrm{CaCO}_{3}$, a mechanism that is favoured by the high $\mathrm{Ca}^{+2}$ concentration in the pore-water.

In conclusion, physical, chemical, and biological mechanisms govern the fast nutrients' benthic regeneration in Lake Honda, while a large pool of nutrients is buried into the sediment of Lake Nueva.

\section{ACKNOWLEDGEMENTS}

We thank Henning Jensen for his valuable suggestions and helpful discussions. This research was supported by the projects CICYT HID 990836 and UE-LIFE B4-3200/98/458. I. de Vicente was supported by a Postdoc grant from the Spanish Ministry of Science and Technology.

\section{REFERENCES}

ADAMS, M. S. \& R. T. PRENTKI. 1986. Sedimentary pigments as an index of the trophic status of Lake Mead. Hydrobiologia, 143: 71-77.

APHA. 1995. Standard methods for the examination of water and wastewater. APHA/ AWWWA/ WPCF. Washington. 1789 pp.

BARICA, J. 1980. Why hypertrophic ecosystems? In: Hypertrophic ecosystems. Development in Hydrobiology 2. J. Barica and L.R. Mur (eds.).: 1-3. Dr. W. Junk Publishers, The Hague-Boston-London.

BARKO, J. W. \& R. M. SMART. 1980. Mobilization of sediment phosphorus by submersed freshwater macrophytes. Freshwat. Biol., 10: 229-238.
BARKO, J. W. \& R. M. SMART. 1981. Sedimentbased nutrition of submersed macrophytes. Aquat. Bot., 10: 339-352.

BARKO, J. W., D. GUNNISON \& S. R. CARPENTER. 1991. Sediment interactions with submersed macrophyte growth and community dynamics. Aquat. Bot., 41: 41-65.

BENAVENTE, J. \& M. RODRÍGUEZ. 2001. Reconocimiento geológico del entorno de las Albuferas de Adra (Almería) a partir de datos geofísicos. Geogaceta, 29: 23-29.

BENAVENTE, J., M. RODRÍGUEZ, M. C. HIDALGO, A. HERMANS \& N. EL AMRANI. 2003. Modelo de funcionamiento hidrogeológico del humedal litoral protegido "Las Albuferas" (Adra, Almería). In: Tecnología de la intrusión de agua de mar en acuíferos costeros. J. A. López -Geta et al. (eds.).: 59-65. IGME. Madrid.

BENNION, H., D. MONTEITH \& P. APPLEBY. 2000. Temporal and geographical variation in lake trophic status in the English Lake District: evidence from (sub) fossil diatoms and aquatic macrophytes. Freshwat. Biol., 45: 394-412.

BLOESCH, J. 1995. Mechanisms, measurement and importance of sediment resuspension in lakes. Mar. Fresh. Res., 46:295-304.

BLOESCH, J. \& N. M. BURNS. 1995. A critical review of sedimentation traps techniques. Schweiz. Z. Hydrol., 42: 15-55.

BOERS, P. C. M. 1986. Studying the phosphorus release from the Loosdrecht lakes sediments, using a continuous flow system. Hydrobiol. Bull., 21: 51-60.

BOSTRÖM, B., J. M. ANDERSEN, S. FLEISCHER \& M. JANSSON. 1988. Exchange of phosphorus across the sediment-water interface. Hydrobiologia, 170: 229-244.

BROBERG, A. 1985. A modified method for studies of electron transport system activity in freshwater sediments. Hydrobiologia, 120: 181-187.

CARIGNAN, R. 1982. An empirical model to estimate the relative importance of roots in phosphorus uptake by aquatic macrophytes. Can. J. Fish. Aquat. Sci., 39: 243-247.

CARIGNAN, R. 1985. Nutrient dynamics in a littoral sediment colonized by the submersed macrophyte Myriophyllum spicatum. Can. J. Fish. Aquat. Sci., 42: 1303-1311.

CARIGNAN, R. \& J. KALFF. 1980. Phosphorus sources for aquatic weeds: water or sediment. Science, 207: 987-989.

CARLTON, R. G. \& R.G. WETZEL. 1988. Phosphorus flux from lake sediments: Effects of 
epipelic algal oxygen production. Limnol. Oceanogr., 33: 562-570.

CARPER, G. L. \& R. W. BACHMANN. 1984. Wind resuspension of sediments in a prairie lake. Can. J. Fish. Aquat. Sci., 41: 1763-1767.

CARRILLO, P., P. SÁNCHEZ-CASTILLO, L. CRUZ-PIZARRO \& R. MORALES. 1996. Cambios cíclicos y tendencias a largo plazo en la salinización de ecosistemas fluctuantes (Albuferas de Adra). Evidencias de eutrofización y contaminación. Limnetica, 12: 59-65.

CHRISTENSEN, K. K. \& F. Ø. ANDERSEN. 1996. Influence of Littorella uniflora on phosphorus retention in sediment supplied with artificial porewater. Aquat. Bot., 55: 183-197.

CLAVERO, V., J. J. IZQUIERDO, J. A. FERNÁNDEZ \& F. X. NIELL. 1999. Influence of bacterial density on the exchange of phosphate between sediment and overlying water. Hydrobiologia, 392: 55-63.

CRUZ-PIZARRO, L., M. ARGAIZ, I. GARZÓN Y J. LÓPEZ. 1992. Batimetría de las lagunas de la Albufera de Adra. Informe técnico. Instituto del Agua-Universidad de Granada. 4 pp.

CRUZ-PIZARRO, L., J. BENAVENTE, J. CASAS, V. AMORES, L. MAY, D. FABIÁN, M. RODRÍGUEZ, K. EL MABROUKI, I. RODRÍGUEZ, I. DE VICENTE, E. MORENOOSTOS, S. L. RODRIGUES DA SILVA, M. BAYO, A. MOÑINO \& M. PARACUELLOS. 2002a. Control de la eutrofización en las lagunas de las Albuferas de Adra. Diagnóstico, Evaluación y Propuesta de Recuperación. Informe Final Proyecto UE LIFE B4-3200/98/458. 349 pp.

CRUZ-PIZARRO, L., V. AMORES, D. FABIÁN, I. DE VICENTE, I. RODRÍGUEZ-PARÍS, K. EL MABROUKI, M. RODRÍGUEZ \& S. L. RODRIGUES DA SILVA. 2002b. La Eutrofización de las Albuferas de Adra (Almería). In: Agricultura y Medio Ambiente en el entorno de las Albuferas de Adra. J. C. Nevado y M. Paracuellos (eds.).: 77-96. Consejería de Medio Ambiente (Almería).

DE MONTIGNI, C. \& Y. T. PRAIRIE. 1993. The relative importance of biological and chemical processes in the release of phosphorus from a highly organic sediment. Hydrobiologia, 253: 141-150.

DE VICENTE, I., 2004. Nutrients exchange acroos sediment-water interface in two coastal eutrophic lakes: Albufera de Adra (Almeria, Spain). Ph D. Dissertation. University of Granada, Granada (Spain). 289 pp.
DE VICENTE, I., L. SERRANO, V. AMORES, V. CLAVERO \& L. CRUZ-PIZARRO. 2003. Sediment phosphate fractionation and interstitial water phosphate concentration in two coastal lakes (Albuferas de Adra, SE Spain). Hydrobiologia, 492: 95-105.

DE VICENTE, I. \& L. CRUZ-PIZARRO. 2003. Estudio de la carga externa e interna de fósforo y aplicación de modelos empíricos de eutrofización en las lagunas de la Albufera de Adra. Limnetica, 22 (1-2): 165-181.

DE VICENTE, I., K. CATTANEO, L. CRUZ-PIZARRO, A. BAUER \& P. GUILIZZONI. 2006. Sedimentary phosphate fractions related to calcite precipitation process in an eutrophic hardwater lake (Lake Alserio, Northern Italy). J. Paleolimnol., 35: 55-64.

DOKULIL, M. T. \& K. TEUBNER. 2003. Eutrophication and restoration of shallow lakesthe concept of stable equilibria revisited. Hydrobiologia, 506/509: 29-35.

DOREMUS, C. \& L. S. CLESCERI. 1982. Microbial metabolism in surface sediments and its role in the inmobilization of phosphorus in oligotrophic lake sediments. Hydrobiologia, 91: 261-268.

DRISCOLL, CH. T., S. W. EFFLER, M. T. AUER, S. M. DOERR \& M. R. PENN. 1993. Supply of phosphorus to the water column of a productive hardwater lake: controlling mechanisms and management considerations. Hydrobiologia, 253: 61-72.

ECKERT, W., A. NISHRI \& R. PARPAROVA. 1997. Factors regulating the flux of phosphate at the sediment-water interface of a subtropical calcareous lake: a simulation study with intact cores. Wat. Air Soil Pollut., 99: 401-409.

ENELL, M. \& S. LÖFGREN. 1988. Phosphorus in interstitial water: methods and dynamics. Hydrobiologia, 170: 103-132.

EVANS, R. D. 1994. Empirical evidence of the importance of sediment resuspension in lakes. Hydrobiologia, 284: 5-12.

GÄCHTER, R. \& J. S. MEYER. 1993. The role of microorganisms in mobilization and fixation of phosphorus in sediments. Hydrobiologia, 253: 103-121.

GÄCHTER, R. \& B. WEHRLI. 1998. Ten years of artificial mixing and oxygenation: no effect on the internal phosphorus loading of two eutrophic lakes. Environ. Sci. Technol., 32: 3659-3665.

GÄCHTER, R. \& B. MÜLLER. 2003. Why the phosphorus retention of lakes does not necessarily depend on the oxygen supply to their sediment surface? Limnol. Oceanogr., 48: 929-933. 
GOLTERMAN, H. L. 1995. The labyrinth of nutrients cycles and buffers in wetlands: results based on research in the Camargue (southern France). Hydrobiologia, 315: 39-58.

GOLTERMAN, H. L. 1996. Fractionation of sediment phosphate with chelating compounds: a simplification and a comparison with other methods. Hydrobiologia, 335: 87-95.

GOLTERMAN, H. L. 1998. The distribution of phosphate over iron-bound and calcium-bound phosphate in stratified sediments. Hydrobiologia, 364:75-81.

GOLTERMAN, H. L. 2001. Phosphate release from anoxic sediments or "What did Mortimer really write?" Hydrobiologia, 450: 99-106.

GOLTERMAN, H. L. 2004. The chemistry of phosphate and nitrogen compounds in sediments. Kluwer Academic Publishers. Dordrecht/ Boston/ London. 246 pp.

GÓMEZ, E., C. DURILlON, G. ROFES \& B. PICOT. 1999. Phosphate adsorption and release from sediments of brackish lakes: $\mathrm{pH}, \mathrm{O}_{2}$ and loading influence. Wat. Res., 33: 2437-2447.

GONZÁLEZ-BERNÁLDEZ，F. 1992. Ecological aspects of wetland/groundwater relationships in Spain. Limnetica, 8: 11-26.

HÅKANSON, L. 1984. On the relationship between lake trophic level and lake sediments. Wat. Res., 18: 303-314.

HÅKANSON, L. \& M. JANSSON. 1983. Principles of lake sedimentology. Springer- Verlag. 316 pp.

HARPER, D. 1992. Eutrophication of freshwaters. Principles, problems and restoration. Chapman and Hall. Londres. 327 pp.

HORPPILA, J. \& L. NURMINEN. 2003. Effects of submerged macrophytes on sediment resuspension and interjnal phosphorus loading in Lake Hiidenvesi (southern Finland). Wat. Res., 37: 4468-4474.

ISTVÁNOVICS, V. \& L. SOMLYÓDY. 1999. Changes in the cycling of phosphorus in the Upper Kis-Balaton Reservoir following external load reduction. Freshwat. Biol., 41: 147-165.

ISTVÁNOVICS, V., L. SOMLYÓDY \& A. CLEMENT. 2002. Cyanobacteria-mediated internal eutrophication in shallow Lake Balaton after load reduction. Wat. Res., 36: 3314-3322.

JAMES, W. F. \& J. W. BARKO. 1990. Macrophytes influences on the zonation of sediment accretion and composition in a north-temperature lake. Arch. Hydrobiol., 20: 129-142.

JENSEN, H. S. \& F. Ø. ANDERSEN. 1992. Importance of temperature, nitrate and $\mathrm{pH}$ for phosphate release from aerobic sediments of four shallow, eutrophic lakes. Limnol. Oceanogr., 37(3): 577-589.

JENSEN, H. S., P. KRISTENSEN, E. JEPPESEN \& A. SKYTTHE. 1992. Iron: phosphorus ratio in surface sediments as an indicator of phosphate release from aerobic sediments in shallow lakes. Hydrobiologia, 235/236: 731-743.

KALFF, J. 2002. Limnology. Prentice Hall. New. Jersey. 592 pp.

KAMP-NIELSEN, L. 1974. Mud- water exchange of phosphate and other ions in undisturbed sediment cores and factors affecting the exchange rates. Arch. Hydrobiol., 73: 218-237.

KELDERMAN, P., H. J. LINDEBOOM \& J. KLEIN. 1988. Light dependent sediment-water exchange of dissolved reactive phosphorus and silicon in a producing microflora mat. Hydrobiologia, 159: 137-147.

KENNER, R. A. \& S. I. AHMED. 1975. Measurement of electron transport activity in marine phytoplankton. Mar. Biol., 33: 119-127.

KRISTENSEN, P., M. SØNDERGAARD \& E. JEPPESEN. 1992. Resuspension in a shallow eutrophic lake. Hydrobiologia, 228: 101-109.

KRISTENSEN, E., S. I. AHMED \& A. H. DEVOL. 1995. Aerobic and anaerobic decomposition of organic matter in marine sediment: Which is fastest? Limnol. Oceanogr., 40: 1430-1437.

LEHTORANTA, J. \& A. S. HEISKANEN. 2003. Dissolved iron:phosphate ratio as an indicator of phosphate release to oxic water of the inner and outlet coastal Baltic Sea. Hydrobiologia, 492: 6984.

LO BIANCO, R. 1997. Analisi paleolimnologiche sul Lago di Candia: primi risultati sul paleoambiente nel corso degli ultimi 4 secoli circa. Tesis de Licenciatura. Universidad de Milán. 140 pp.

LOTTER, A. F. 2001. The paleolimnology of Soppensee (Central Switzerland), as evidenced by diatom, pollen and fossil-pigment analyses. $J$. Paleolimnol., 25: 65-79.

LUNDQVIST, G. 1938. Sjösediment från Bergslagen (Kolbäcksåns vattenormråde). Sver. Geol. Unders. Afh. No. 420, 186 pp.

LUNDQVIST, G. 1942. Sjösediment och deras bildningsmiljö. Sver. Geol. Unders. Afh. No. 444, 126 pp.

LUQUE, J. A. \& R. JULIÁ. 2002. Lake sediment response to land-use and climate change during the last 1000 years in the oligotrophic Lake Sanabria (northwest of Iberian Peninsula). Sed. Geol., 148: 343-355. 
MANN, K. H. 1982. Ecology of coastal waters. A systems approach. Blackwell Scientific publications. Oxford. $322 \mathrm{pp}$.

MARTÍNEZ VIDAL, J. L. \& H. CASTRO (coords.). 1990. Las Albuferas de Adra. Estudio Integral. Colección Investigación, 9. Instituto de Estudios Almerienses (Diputación Provincial de Almería). Almería. $314 \mathrm{pp}$.

MARTINOVA, M. V. 1993. Nitrogen and phosphor compounds in bottom sediments: mechanism of accumulation, transformation and release. Hydrobiologia, 252: 1-22.

MARSDEN, M. W. 1989. Lake restoration by reducing external phosphorus loading: the influence of sediment phosphorus release. Freshwat. Biol., 21: 139-162.

MORTIMER, C. H. 1941. The exchange of dissolved substances between mud and water in lakes. I. $J$. Ecol., 30: 280-329.

MORTIMER, C. H. 1971. Chemical exchanges between sediments and water in the Great Lakesspeculations on probable regulatory mechanisms. Limnol. Oceanogr., 16: 387-404.

MURPHY, J. \& J. P. RILEY. 1962 A modified single solution method for the determination of phosphate in natural waters. Anal. Chim. Acta, 27: 31-36.

MUSAZZI, S. 2000. Ricostruzione paleolimnologica dell'evoluzione trofica del Lago Maggiore nel corso del XX secolo. Tesis de Licenciatura. Universidad de Milán. 130 pp.

NEWRKLA, P. 1982. Annual cycles of benthic community oxygen uptake in a deep oligotrophic lake (Attersee, Austria). Hydrobiologia, 94: 139-147.

NÕGES, P., L. TUVIKENE, T. NÕGES \& A. KISAND. 1999. Primary production, sedimentation and resuspension in large shallow Lake Võrtsjärv. Aquat. Sci., 61: 168-182.

OSGOOD, R. A. 1988. A hypothesis on the role of Aphanizomenon in translocating phosphorus. Hydrobiologia, 169: 69-76.

PETERS, R. H. \& A. CATTANEO. 1984. The effects of turbulence on phosphorus supply in a shallow bay of Lake Memphremagog. Verh. Internat. Verein. Limnol., 22: 185-189.

PETTERSSON, K., E. HERLITZ \& V. ISTVÁNOVICS. 1993. The role of Gloeotrichia echinulata in the transfer of phosphorus from sediments to water in Lake Erken. Hydrobiol., 253: 123-129.

QIU, S. \& A. J. McCOMB. 1995. The plankton and microbial contribution to phosphorus release from fresh and air-dried sediments. Mar. Freshwater Res., 46: 1039-1045.
RELEXANS, J. C. 1996. Measurement of respiratory electron system (ETS) activity in marine sediments. State of the art and interpretation II. Significance of ETS activity date. Mar. Ecol. Prog. Ser., 136: 289-301.

RELEXANS, J. C., H. ETCHEBER, J. CASTEL, V. ESCARAVAGE \& I. AUBY. 1992. Benthic respiratory potential with relation to sedimentary carbon quality in seagrass beds and oyster parks in the tidal flats of Arcachon Bay, France. Estuar. Coast Shelf Sci., 34: 157-170.

ROBINSON, G. W. 1922. New method for mechanical analysis of soil and another dispersion. J. Agr. Ac., 12: 306-321.

RODIER, J. 1989. Análisis de las aguas. Omega. Barcelona. 1059 pp.

RYDING, S. O. 1985. Chemical and microbiological processes as regulators of the exchange of substances between sediments and water in shallow eutrophic lakes. Int. Revue ges. Hydrobiol., 70: 657-702.

RYDING, S. O. \& W. RAST. 1992. El control de la eutrofización en lagos y pantanos. Pirámide. Madrid. 357 pp.

SAS, H. 1989. Lake restoration and reduction of nutrient loading: expectations, experiences and extrapolations. Academia Verlag Richarz, St. Augustin. 497 pp.

CHAUSER, I., J. LEWANDOWSKI \& M. HUPFER. 2003. Decision support for the selection of an appropriate in-lake measure to influence the phosphorus retention in sediments. Wat. Res., 37: 801-812.

SCHMIDT, R., K. A. KOINIG, R. THOMPSON \& C. KAMENIK. 2002. A multi proxy core study of the last 7000 years of climate and alpine land-use impacts on an Austrian mountain lake (Unterer Landschitzsee, Niedere Tauern). Paleogeography, Paleoclimatology, Paleoecology, 187: 101-120.

SERRANO, L., I. DE VICENTE, M. REINA, J. TOJA \& L. CRUZ-PIZARRO. 2005. Phosphate release from sediments in hypertrophic coastal lagoons of southern Spain. In: Phosphate in sediments. L. Serrano and H.L. Golterman (eds.).: 6775. Proceedings of the $4^{\text {th }}$ International Symposium. Blackhuys Publishers.

SINKE, A. J. C. \& T. E. CAPPENBERG. 1988. Influence of bacterial processes on the phosphorus release from sediments in a eutrophic Loosdrecht Lakes, The Netherlands. Arch. Hydrobiol. Beih. Ergebn. Limnol., 30: 5-13.

SOMMARUGA, R. 1991. Sediment oxygen demand in man-made Lake Ton-Ton (Uruguay). Hydrobiologia, 215: 215-221. 
SØNDERGAARD, M., P. KRISTENSEN \& E. JEPPESEN. 1992. Phosphorus release from resuspended sediment in the shallow and windexposed Lake Arresø, Denmark. Hydrobiologia, 228: 91-99. SØNDERGAARD, M., J. P. JENSEN \& E. JEPPESEN. 1999. Internal phosphorus loading in shallow Danish lakes. Hydrobiologia, 408/409: 145-152.

TÓTH, L. G. 1992. Respiratory electron transport system (ETS)- activity of the plankton and sediment in Lake Balaton (Hungary). Hydrobiologia, 243/244: 157-166.

TÓTH, L. G. 1994. Terminal electron transport system (ETS)- activity in the sediment of Lake Balaton, Hungary. Hydrobiologia, 281: 129-139.

TREVORS, J. T. 1984. The measurement of electron transport system (ETS) activity in freshwater sediment. Water Res., 18: 581-584.
WAINRIGHT, S. C. \& C. S. HOPKINSON. 1997. Effects of sediment resuspension on organic matter processing in coastal environments: a simulation model. J. Mar. Syst., 11: 353-368.

WATTS, C. J. 2000. The effect of organic matter on sedimentary phosphorus release in an Australian reservoir. Hydrobiologia, 431: 13-25.

WEYHENMEYER, G. A., M. MEILI \& D. C. PIERSON. 1995. A simple method to quantify sources of settling particles in lakes: Resuspension versus new sedimentation of material from planktonic production. Mar. Fresh. Res., 46: 223-231.

WEYHENMEYER, G.A. \& J. BLOESCH. 2001. The pattern of particle flux variability in Swedish and Swiss lakes. Sci. Total Environ., 266: 69-78. 